\title{
Sintering of $\mathrm{MnC} 2 \mathrm{O} 4$ coatings prepared by electrophoretic deposition
}

\author{
Bobruk, M.; Molin, Sebastian; Chen, Ming; Brylewski, T.; Hendriksen, Peter Vang
}

Published in:

Materials Letters

Link to article, DOI:

10.1016/j.matlet.2017.12.046

Publication date:

2018

Document Version

Peer reviewed version

Link back to DTU Orbit

Citation (APA):

Bobruk, M., Molin, S., Chen, M., Brylewski, T., \& Hendriksen, P. V. (2018). Sintering of $\mathrm{MnCo}_{2} \mathrm{O}_{4}$ coatings prepared by electrophoretic deposition. Materials Letters, 213, 394-398.

https://doi.org/10.1016/j.matlet.2017.12.046

\section{General rights}

Copyright and moral rights for the publications made accessible in the public portal are retained by the authors and/or other copyright owners and it is a condition of accessing publications that users recognise and abide by the legal requirements associated with these rights.

- Users may download and print one copy of any publication from the public portal for the purpose of private study or research.

- You may not further distribute the material or use it for any profit-making activity or commercial gain

- You may freely distribute the URL identifying the publication in the public portal

If you believe that this document breaches copyright please contact us providing details, and we will remove access to the work immediately and investigate your claim 


\title{
Sintering of $\mathrm{MnCo}_{2} \mathrm{O}_{4}$ coatings prepared by electrophoretic deposition
}

\author{
M. Bobruk', S. Molin ${ }^{b *}$, M. Chen ${ }^{b}$, T. Brylewski ${ }^{a}$, P.V. Hendriksen ${ }^{b}$ \\ ${ }^{\text {a }}$ Faculty of Materials Science and Ceramics, AGH University of Science and Technology, \\ al.Mickiewicza 30, 30-059 Krakow, Poland \\ ${ }^{b}$ Department of Energy Conversion and Storage, Technical University of Denmark, \\ Frederiksborgvej 399, 4000 Roskilde, Denmark
}

*e-mail: sebmo@dtu.dk

\begin{abstract}
Sintering of $\mathrm{MnCO}_{2} \mathrm{O}_{4}$ coatings prepared by electrophoretic deposition on steel substrates has been studied in air and in reducing-oxidizing atmosphere. Effect of temperature and $\mathrm{pO}_{2}$ on the resulting coating density was evaluated from scanning electron microscopy images of polished cross sections. Best sample microstructure was found after a reduction at $1000^{\circ} \mathrm{C}$ and reoxidation at $900^{\circ} \mathrm{C}$ treatment.
\end{abstract}

\section{Keywords}

Electrophoretic deposition; SOFC; protective coating; interconnect; ceramics; oxidation;

\section{Introduction}

$(\mathrm{Mn}, \mathrm{Co})_{3} \mathrm{O}_{4}$ spinels are promising materials for protective coatings for steel interconnects used in high temperature solid oxide fuel/electrolysis stacks [1,2]. Many different deposition methods and sintering conditions have been applied and described in available literature [3], including electrophoretic deposition [4-6]. Effective sintering of coatings based on a reduction-oxidation procedure has been proposed by Yang et al. [7]. However, no systematic study of the influence of both the temperature and gas composition on the achievable coating density has been reported so far.

This work evaluates the influence of the gas composition and reduction temperature on sintering of a commercial $\mathrm{MnCO}_{2} \mathrm{O}_{4}$ powder deposited on Crofer $22 \mathrm{APU}$ steel by electrophoretic deposition. 


\section{Experimental}

A commercial $\mathrm{MnCo}_{2} \mathrm{O}_{4}$ powder (FuelCellMaterials, USA) was used to prepare coatings on $0.3 \mathrm{~mm}$ thick Crofer 22 APU samples. The steel sheet was cut to $20 \times 20 \mathrm{~mm}^{2}$ and a small hole $3 \mathrm{~mm}$ in diameter was punched in each piece to allow hanging of the sample during the coating and in the furnace. The electrophoretic deposition of the coating was performed in a Teflon container of $\sim 150 \mathrm{ml}$ volume. A mixture of ethanol and isopropanol (50:50) was used as a solvent. The solid loading of the slurry was 1 wt.\%. As a dispersant, $0.5 \mathrm{~g} / \mathrm{L}$ iodine (Aldrich, Denmark) was added and milled on a roll-mill with zirconia balls for 5 days. The deposition was carried out at $60 \mathrm{~V}$ for 1 minute using a symmetrical setup with a stainless steel counter electrodes placed $15 \mathrm{~mm}$ from the sample. The procedure has been described in details in [8]. After the deposition, the coated samples were sintered in a tube furnace under a flowing gas, as described in the results section. Ramping rates during heating and cooling were always $120^{\circ} / \mathrm{h}$.

Materials analyses have been performed using Bruker D8 Advance x-ray diffractometer (XRD) and Hitachi TM3000 scanning electron microscope (SEM) with na energy dispersive spectroscopy (EDS) detector.

\section{Results and Discussion}

The microstructure, the XRD pattern and the particle size distribution of the applied $\mathrm{MnCo}_{2} \mathrm{O}_{4}$ powder are presented in Figure 1. The powder has a bimodal size distribution with $d_{50}=0.81 \mu \mathrm{m}$ and $d_{90}=1.23$ $\mu \mathrm{m}$. According to the EDS analysis (inset in Figure $1 \mathrm{~A}$ ), the ratio of Co to $\mathrm{Mn}$ in the raw powder is higher than 2 and the raw powder contains $\mathrm{Al}$, most probably in the form of $\mathrm{Al}_{2} \mathrm{O}_{3}$ residues after milling, these were however not detected by XRD, where a phase pure cubic spinel structure is found.

Figure 1. Analysis of the starting powder: (A) SEM, (B) XRD and (C) particle size analysis.
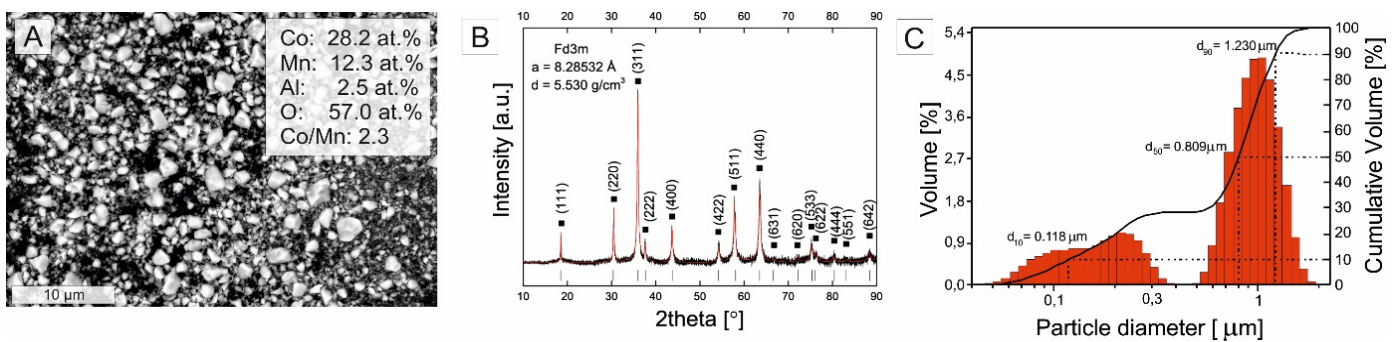
Powders were deposited on steel substrates according to procedure described in [8]. First, results from sintering in air shall be discussed. Sintering was carried out at $900^{\circ} \mathrm{C}, 1000^{\circ} \mathrm{C}$ and $1100^{\circ} \mathrm{C}$ for 2 hours. The resulting microstructures are shown in Figure 2. For the sample sintered at $900^{\circ} \mathrm{C}$ only a minor densification is observed and the microstructure is similar to the as-produced, "green" coatings. After sintering at $1000^{\circ} \mathrm{C}$, some densification is visible, but the coating is still porous with open pores. Densification of the few $\mu \mathrm{m}$ thick layer next to steel/chromia (marked as "dense spinel") occur due to a diffusion of $\mathrm{Cr} / \mathrm{Mn}[2]$. After a $1100^{\circ} \mathrm{C}$ firing the coating has densified significantly, but also some cracks are observed at the chromia/spinel interface. Significant growth of a chromia scale is visible on samples sintered at $1000^{\circ} \mathrm{C} / 1100^{\circ} \mathrm{C}$.

Figure 2. SEM/EDS cross sections after sintering in air.

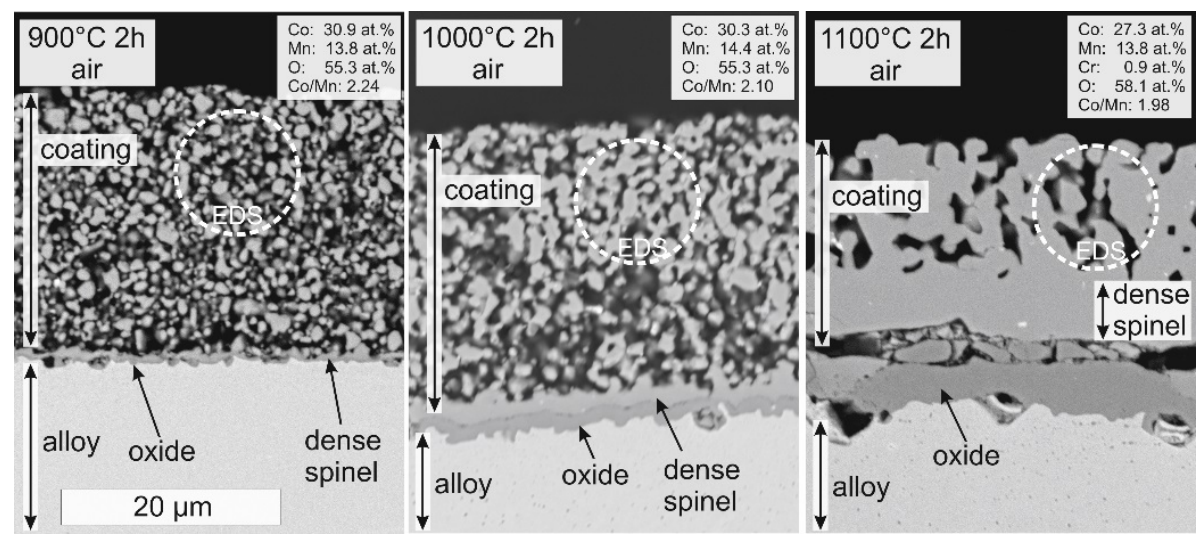

In the next step, sintering via a reduction-oxidation (reactive sintering) process has been evaluated. In this method, coatings are first reduced, forming metallic $\mathrm{Co}$ and $\mathrm{MnO}$ and then are reoxidized, reforming the spinel with a higher density [7].

For the reduction step, three different reducing atmospheres were evaluated. These were obtained by using a "dry" mixture of hydrogen and argon (9:91 vol.\%) or bubbling it through water bath held at either $7^{\circ} \mathrm{C} / 25^{\circ} \mathrm{C}\left(1 \% / 4 \%\right.$ steam in equilibrium). Respective equilibrium $\mathrm{pO}_{2}$ levels (calculated by FactSage 6.4) are given in Table 1. It has been assumed, that steam content in the dry gas is $1 \mathrm{ppm}$. 
Table 1. $\mathrm{pO}_{2}$ values calculated for gas mixtures and temperatures used in this study.

\begin{tabular}{|c|c|c|c|}
\hline & dry gas & $1 \% \mathrm{H}_{2} \mathrm{O}$ & $4 \% \mathrm{H}_{2} \mathrm{O}$ \\
\hline $900^{\circ} \mathrm{C}$ & $6.23 \mathrm{E}-27$ & $6.24 \mathrm{E}-19$ & $10 \mathrm{E}-18$ \\
\hline $1000^{\circ} \mathrm{C}$ & $3.44 \mathrm{E}-25$ & $3.45 \mathrm{E}-17$ & $5.51 \mathrm{E}-16$ \\
\hline $1100^{\circ} \mathrm{C}$ & $1.15 \mathrm{E}-23$ & $1.10 \mathrm{E}-15$ & $1.71 \mathrm{E}-14$ \\
\hline
\end{tabular}

The microstructures of the coatings after reduction at $900^{\circ} \mathrm{C}, 1000^{\circ} \mathrm{C}$ and $1100^{\circ} \mathrm{C}$ in different atmospheres are shown in Figure 3. The main effect of the temperature increase is the growth of metallic cobalt particles. At $1100^{\circ} \mathrm{C}$ the cobalt even forms single grains through the entire coating thickness. No reaction between the coating material and the steel substrate occurred. Both the temperature and gas composition have an effect on the oxidation of the steel taking place during the heat treatment. For different atmospheres/temperatures, different oxide scale thicknesses are obtained as presented in Figure 3. It is clearly beneficial to use atmospheres with lower $\mathrm{pH}_{2} \mathrm{O}$ (and thus lower $\mathrm{pO}_{2}$ ) due to noticeably lower thickness of the chromia layer formed.

Figure 3. SEM/EDS cross sections of coatings after reduction. 


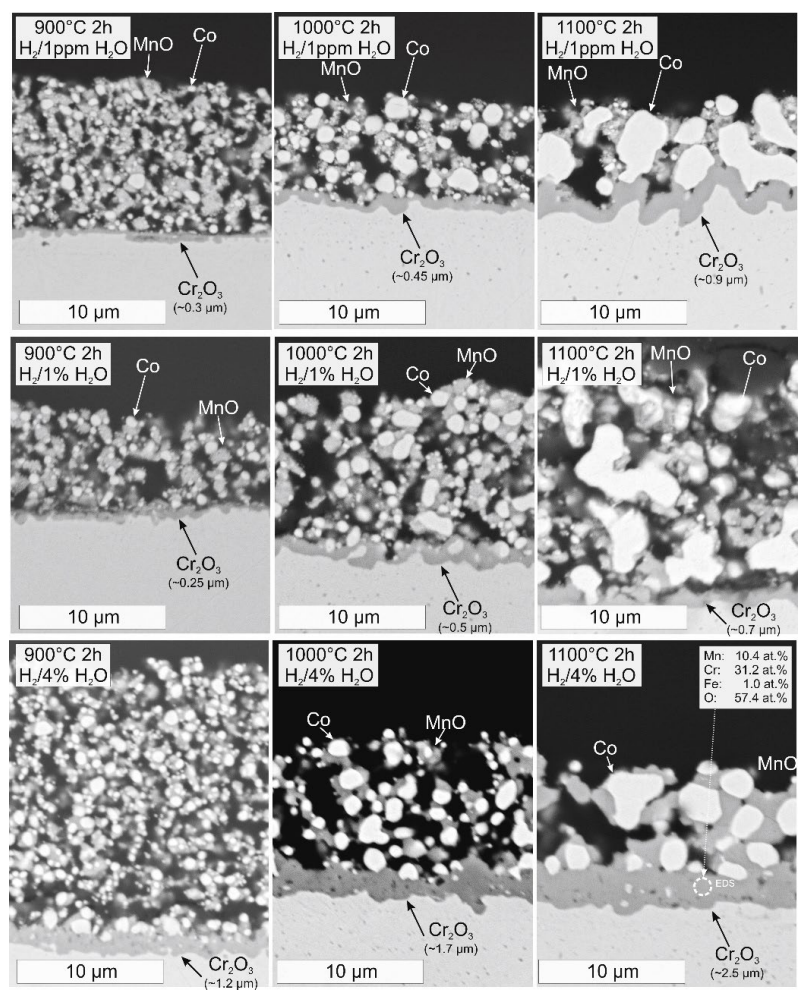

For the reoxidation step, a temperature of $900^{\circ} \mathrm{C}$ for 2 hours was selected. Sample microstructures after the initial reduction are shown in Figure 3 and images after reoxidation in Figure 4. Coatings reduced and reoxidized at $900^{\circ} \mathrm{C}$ show open porosity for all atmospheres, which would allow for gas access to the interface of the alloy/oxide. Comparing to coatings sintered only in the air, the reduction step clearly enhances the densification. Especially for reduction performed at $1000^{\circ} \mathrm{C}$ and $1100^{\circ} \mathrm{C}$, microstructures of the reoxidized samples show visibly denser coatings. Some porosity is still visible, especially at samples reduced at $1000^{\circ} \mathrm{C}$, but it seems to be closed porosity mainly. The densest coatings, obtained via reduction at $1100^{\circ} \mathrm{C}$ showed enhanced tendency of cracking on the cross section and on the surface. Coatings obtained by reduction/oxidation using gas with $4 \%$ steam show slightly higher porosity than other samples treated at the same temperatures.

At several spots across the oxidized coatings, small bright particles are visible. These $\mathrm{Zr}$ rich contaminants come from the ball milling step and got deposited during the EPD process. Presence of this refractory phase might have a negative effect on the sintering.

After the reoxidation, the chromia scale is a little difficult to distinguish from the now oxidized coating. It is marked in marked in Figure 4 by a dashed line. In addition to the chromia scale, $\mathrm{Cr}$ reacted with Co 
and $\mathrm{Mn}$ forming a dense reaction layer, visible as a slightly darker grey region. For samples reduced at $1100^{\circ} \mathrm{C}$, the chromia scale after reoxidation is thinner than after the reduction. The reaction layer in turn contains $\sim 10$ at.\% of $\mathrm{Cr}$, originating from the chromia layer formed after reduction. Comparing the chemical composition of the coatings reduced in $1 \%$ steam hydrogen/Ar mixture, some diffusion of Fe and $\mathrm{Cr}$ from the alloy/oxide to the coating is detected. With increasing the temperature, the Co/Mn ratio increases, possibly due to evaporation of $\mathrm{Mn}$ at high temperatures.

Comparing Figures 3 and 4, the aggregation of Co into large particles during the reduction step seems to play a key role in the densification of the coatings in the subsequent oxidation. Evidently, the density of the coatings can be to some degree tailored using appropriate reduction temperature and time prior to the reoxidation.

Figure 4. SEM/EDS cross sections of coatings after reduction and reoxidation.

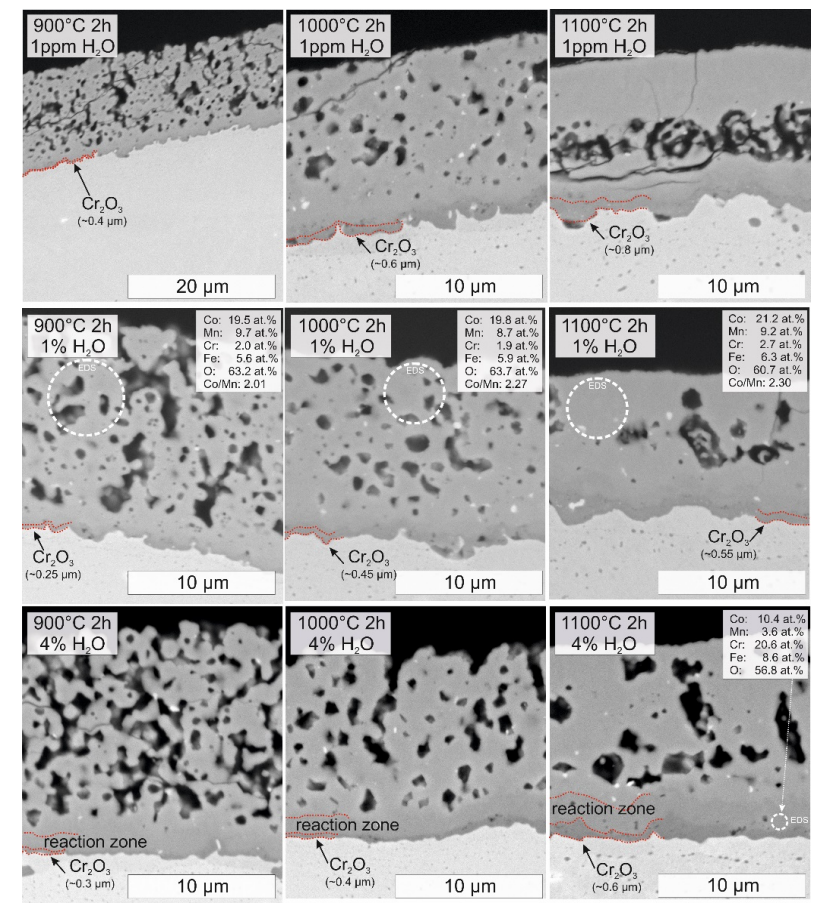

\section{Summary}

In this work sintering of protective $\mathrm{MnCo}_{2} \mathrm{O}_{4}$ coatings deposited by electrophoretic deposition was studied. Results show that maintaining a low $\mathrm{pO}_{2} / \mathrm{pH}_{2} \mathrm{O}$ during the reduction stage minimizes chromia growth. From microstructure analysis it is shown that the coarsening of Co during the reduction has a strong influence on the final coating density obtained after the reoxidation. Coatings reduced at $900^{\circ} \mathrm{C}$ 
will provide some corrosion protection via the dense reaction layer formed at the coating/chromia interface, but a large part of the coating will remain porous. At $1100 \mathrm{C}$ the thickest chromia layer has formed, pores have coalesced forming large $(>10 \mu \mathrm{m})$ structures and in some cases cracks are observed. The best microstructure, with a thinner chromia and a dense coating is observed for pre-reduction in hydrogen/ $\mathrm{Ar}$ (containing $1 \% \mathrm{H}_{2} \mathrm{O}$ ) at $1000^{\circ} \mathrm{C}$ and reoxidation in air at $900^{\circ} \mathrm{C}$.

\section{Acknowledgement}

DTU Energy acknowledges support from the project 2015-1-12276 “Towards solid oxide electrolysis plants in 2020", ForskEL energienet.dk.

\section{References:}

[1] Y. Larring, T. Norby, Spinel and Perovskite Functional Layers Between Plansee Metallic Interconnect ( $\mathrm{Cr}-5$ wt.\% Fe-1 wt.\% $\mathrm{Y}_{2} \mathrm{O}_{3}$ ) and Ceramic $\left(\mathrm{La}_{0.85} \mathrm{Sr}_{0.15}\right)_{0.91} \mathrm{MnO}_{3}$ Cathode Materials for Solid Oxide Fuel Cells, J. Electrochem. Soc. 147 (2000) 3251-3256.

[2] S. Molin, P. Jasinski, L. Mikkelsen, W. Zhang, M. Chen, P.V. Hendriksen, Low temperature processed $\mathrm{MnCo}_{2} \mathrm{O}_{4}$ and $\mathrm{MnCO}_{1.8} \mathrm{Fe}_{0.2} \mathrm{O}_{4}$ as effective protective coatings for solid oxide fuel cell interconnects at $750{ }^{\circ} \mathrm{C}$, J. Power Sources. 336 (2016) 408-418.

[3] L.C. Ajitdoss, F. Smeacetto, M. Bindi, D. Beretta, M. Salvo, M. Ferraris, $\mathrm{Mn}_{1.5} \mathrm{Co}_{1.5} \mathrm{O}_{4}$ protective coating on Crofer 22 APU produced by thermal co-evaporation for SOFCs, Mater. Lett. 95 (2013) 82-85.

[4] F. Smeacetto, A. De Miranda, S. Cabanas Polo, S. Molin, D. Boccaccini, M. Salvo, et al., Electrophoretic Deposition of $\mathrm{Mn}_{1.5} \mathrm{Co}_{1.5} \mathrm{O}_{4}$ on Metallic Interconnect and Interaction with Glass-ceramic Sealant for Solid Oxide Fuel Cells Application, J. Power Sources. 280 (2015) 379-386.

[5] Y. Zhang, A. Javed, M. Zhou, S. Liang, P. Xiao, Fabrication of Mn-Co Spinel Coatings on Crofer 22 APU Stainless Steel by Electrophoretic Deposition for Interconnect Applications in Solid Oxide Fuel Cells, Int. J. Appl. Ceram. Technol. 11 (2014) 332-341.

[6] H. Abdoli, P. Alizadeh, Electrophoretic deposition of $(\mathrm{Mn}, \mathrm{Co})_{3} \mathrm{O}_{4}$ spinel nano powder on SOFC metallic interconnects, Mater. Lett. 80 (2012) 53-55. 
[7] Z. Yang, G. Xia, S.P. Simner, J.W. Stevenson, Thermal Growth and Performance of Manganese Cobaltite Spinel Protection Layers on Ferritic Stainless Steel SOFC Interconnects, J. Electrochem. Soc. 152 (2005) A1896-A1901.

[8] D. Szymczewska, S. Molin, V. Venkatachalam, M. Chen, P. Jasinski, P.V. Hendriksen, Assessment of $(\mathrm{Mn}, \mathrm{Co})_{3} \mathrm{O}_{4}$ powders for possible coating material for SOFC/SOEC interconnects, IOP Conf. Ser. Mater. Sci. Eng. 104 (2016) 12017. 